al-Ihkam: Jurnal Hukum dan Pranata Sosial, 16 (1), 2021: 111 -136

ISSN: 1907-591X, E-ISSN: 2442-3084

DOI: http://doi.org/10.19105/al-lhkam.v16i1.4550

\title{
Building the Values of Rahmatan Lil 'Alamin for Indonesian Economic Development at 4.0 Era from the Perspective of Philosophy and Islamic Economic Law
}

\author{
Hisam Ahyani \\ Islamic University of Miftahul Huda Al Azhar (STAIMA) Banjar City, West Java, \\ Indonesia, and Student of Doctoral program in Islamic Law, Consestration of Sharia \\ Economic Law, UIN Sunan Gunung Djati, Bandung, Indonesia \\ email: hisamahyani@gmail.com \\ Memet Slamet \\ Islamic University of Miftahul Huda Al Azhar (STAIMA) Banjar City, \\ West Java, Indonesia, Email : memetslamet534@gmail.com \\ Tobroni \\ SMKN 1 Jatibarang Indramayu Regency, West Java, Indonesia, and Gradutes \\ Master's Program UIN Sunan Gunung Djati, Indonesia. Email : \\ ibnurusyd.publising@gmail.com
}

Article history: Received: Mei 07, 2021, Accepted: May 23, 2021, Published: Juni 27, 2021

\begin{abstract}
:
This research aims to build the value of rahmatan lil 'alamin in Indonesian economic development at 4.0 eras from the perspective of philosophy and shariah economic law. The role of both is considered important regarding with freedom to do any economic activities in Indonesia as the non-Islamic state in the formal term yet at the same time is known as a sharia economic community due to its world's largest Moslem population. This literature-normative research is qualitative with a statutory, historical, comparative, and conceptual approach. It found that first, rahmatan lil 'alamin value enables the philosophy of Islamic law to develop the Indonesian economy. The goal of Islam as a religion is to guide its believers toward the happiness of the world and the hereafter and the triangle concept among philosophy of God, human, and nature, for example, make it possible for Islamic economic with its rahmatan lil 'alamin
\end{abstract}

Author correspondence email: hisamahyani@gmail.com Available online at: http:/ / ejournal.iainmadura.ac.id/index.php/alihkam/ Copyright (c) 2021 by al-ihkam. All Right Reserved 
values to cover the weakness of the conventional economic system. Second, the rahmatan lil 'alamin in Islamic economics law can be manifested by organizing social services, such as waqf, relying on the spirit of building justice in life, narrowing social gaps, as well as enlivening Islamic values. In the era of 4.0, the implementation of the value can be adjusted to recent demands and situations, such as cash waqf, halal industry, halal food, halal tourism, and so on.

\title{
Keywords:
}

Philosophy; Economic Sharia; Rahmatan Lil' Alamin; Economic in 4.0 Era

\begin{abstract}
Abstrak:
Riset ini bertujuan menggali nilai-nilai rahmatan lil 'alamin dalam perekonomian Indonesia era 4.0 menurut tinjauan filsafat dan hukum ekonomi syariah. Peran keduanya dianggap penting terkait kebebasan berekonomi dalam konteks Indonesia yang bukan merupakan negara Islam secara formal namun memiliki komunitas ekonomi Syariah sebagai negara Muslim terbesar di dunia. Penelitian kepustakaan-normatif ini bersifat kuantitatif dengan pendekatan perundang-undangan, sejarah, perbandingan, serta konseptual. Pada penelitian ini ditemukan bahwa pertama, dengan menggunakan konsep rahmatan lil 'alamin, memungkinkan filsafat hukum Islam untuk berkontribusi dalam mengembangkan perekonomian Indonesia. Tujuan Islam untuk mencapai kebahagiaan dunia-akhirat serta konsep segitiga antar filsafat Tuhan, manusia, dan alam, misalnya, menutupi kekurangan dalam sistem ekonomi konvensional dengan sistem ekonomi Islam. Kedua, nilai rahmatan lil 'alamin dalam hukum ekonomi Islam dapat diwujudkan dengan menyelenggarakan kegiatan-kegiatan sosial seperti wakaf dengan semangat menciptakan kehidupan yang berkeadilan, mengurangi kesenjangan sosial serta menghidupkan nilai-nilai keislaman. Di era 4.0, implementasi nilai rahmatan lil'alamin dapat disesuaikan dengan tuntutan zaman semisal wakaf tunai, industri halal, makanan halal, wisata halal, dan lain sebagainya.
\end{abstract}

\section{Kata Kunci:}

Filsafat; Ekonomi Syariah; Rahmatan Lil ‘Alamin; Ekonomi Era 4.0 


\section{Introduction}

Islam is a complete religion which not only teaches worship but also it practices in the social realm (muamalah). Islam has perfectly explained business ethics such as honesty, openness, and others which will ultimately benefit all parties. In addition, Islamic financial instruments are also very diverse. There are financial instruments intended for business, for example, buying and selling, or in Arabic it is called bai', for example, bai' murabahah. Leasing which in Arabic is also called ijarah and cooperation which in Arabic is called syirkah. Besides, Islam also explains financial instruments to overcome social problems. Poverty and underdevelop are problems that are faced before era 4.0, and we need instruments such as zakat and waqf. As we all know, zakat and waqf in Indonesia are growing rapidly. The awareness of the Indonesian people to pay tithe and waqf either through cash waqf or other forms of waqf is also increasing. This is something to be grateful for considering that the two instruments focus on meeting basic needs, which not all elements of society enjoy. The complexity of building public awareness in terms of zakat and waqf needs to be done through several accurate strategies including applying the concept of Rahmatan Lil 'Alamin as the main basis for a Muslim as a companion to human life in the field of Mu'amalah.

The wealth which is one of the gifts of Allah SWT given for human welfare, its existence for humans is very important as one of the supports for survival. But that does not mean that wealth is the ultimate goal in human life because it is only a means to seek eternal life, namely in the hereafter. So Allah SWT also gives syar'i rules that must be followed and obeyed by humans in practicing their assets. ${ }^{1}$ Research by Nur Liviasari Yulma and Sri Herianingrum provides training to empowerment targets, for example in empowerment at the Roudlotul Hikam Islamic boarding school. Based on the availability indicators, relevance indicators, affordability indicators, utilization indicators, quality indicators, efficiency indicators, the role of BMT Amanah Ummah as a fund-raising institution cash waqf as nazhir can

\footnotetext{
${ }^{1}$ Nur Liviasari Yulma and Sri Herianingrum, "Peran Pemberdayaan Wakaf Tunai (Studi Kasus Pada BMT Amanah Ummah Surabaya)," Jurnal Ekonomi Syariah Teori Dan Terapan 3, no. 11 (2016): 856-71, https://doi.org/10.20473/vol3iss201611pp856-871.
} 
be said to be good because it can collect, manage, and distribute cash waqf on target. This can be seen from how the success indicators of the empowerment program are under the cash waqf program from BMT Amanah Ummah. From this example, it can be seen that the concept of Rahmatan Lil 'Alamin (overshadowing the entire ummah) is expected to be able to make the concept exist. This requires the development and in-depth study of the Philosophy of Islamic Law, which is then implemented and developed through the economic field in Indonesia. Rahmatan Lil 'Alamin today can be used as a complement or method of Indonesia's economic development where the shortcomings of the conventional economic system can be complemented by an Islamic economic system. It also needs proof of the concept of Rahmatan Lil 'Alamin was to think deeply in terms of the philosophy of Islamic economic law to this concept which is based on the triangle concept, namely the philosophy of God, humans, and nature.

The same thing concluded by Abdur Rohman ${ }^{2}$ in his journal that Islam is a universal and comprehensive religion. This means that Islam Rahmatan Lil 'Alamin is an umbrella that universally covers every human being, which can be used for all mankind on earth and can be applied at any time and place until the end of time. The perfection of Islamic teachings regulates all aspects of human life, not only spiritual aspects (pure worship), but also mu'amalah aspects which include economic, social, political, legal, and so on. As comprehensive teaching, Islam includes three main teachings, namely aqidah, shari'ah, and morals. The relationship between aqidah, shari'ah, and morals in the Islamic system is interwoven in such a way that it is a comprehensive system. Islamic Sharia is divided into two, namely worship and mu'amalah. Included in the study of mua'amalah is buying and selling which puts forward the principle of 'an-taradlin' (mutual pleasure). Therefore, this paper tries to review philosophically the meaning and concept as well as its implementation in the study of Islamic economic law.

2 Abdur Rohman, “Menyoal Filosofi 'An Taradin Pada Akad Jual Beli (Kajian Hukum Ekonomi Syariah Dalam Transaksi Jual Beli)," Et-Tijarie: Jurnal Hukum Dan $\begin{array}{lllll}\text { Bisnis Syariah no. } & 2016) \text {, }\end{array}$ https://journal.trunojoyo.ac.id/ettijarie/article/view/3911. 
In the case of Waqf, for example, KNKS (the Sharia Finance National Committee) supports all forms of collaboration between national and international stakeholders, particularly in the development of the halal industry. It can be in the form of halal food, halal tourism, and other halal products. Through this opportunity, KNKS supports the formation of a commitment to cooperation by halal industry players between countries through waqf financing schemes. ${ }^{3}$ The essence of waqf, for example, is exemplified by Qurratul 'Aini Wara Hastuti in her research that the principal of the waqf asset should not be reduced. Assets that have been handed over by the wakif or waqf giver to the nazir or the waqf manager must be properly maintained by the nazir. Nazir was responsible for raising these assets. Nazir must be held responsible when the asset is reduced. The business and social orientation that exists in waqf is waqf, especially cash waqf received by nazir must be invested to seek profit as large as possible to be given to mauquf alaih or waqf beneficiaries. The goal of looking for profitable business opportunities is to help as many mauquf alaih as possible. In this case, of course, there needs to be cooperation between fellow financial institutions receiving cash waqf, but as we can see, this cooperation has not yet been seen, and it seems that each institution runs independently. Based on the things above, the author is interested in discussing the role of Islamic financial institutions receiving cash waqf (LKS-PWU) for optimizing cash waqf. ${ }^{4}$

Kusuma in his research explains that: ${ }^{5}$ Islam is not just a belief in certain things in life but is a concept that conveys and connects all aspects of life which can be called a belief system. Islam teaches that all aspects of natural life are Allah's will and property; therefore there is no distinction between life in this world and life after death. There

3 "Wakaf Go Global : Kembangkan Inovasi Wakaf Produktif Untuk Industri Halal," Komite Nasional Ekonomi dan Keuangan Syariah, accessed April 9, 2021, https:/ / knks.go.id/berita/85/wakaf-go-global-kembangkan-inovasi-wakafproduktif-untuk-industri-halal?category $=1$.

${ }^{4}$ Qurratul 'Aini Wara Hastuti, "Peran Lembaga Keuangan Syariah Penerima Wakaf Uang (LKS-PWU) Bagi Optimalisasi Wakaf Uang," Ziswaf: Jurnal Zakat Dan Wakaf 4, no. 1 (February 15, 2018): 41-54, https:/ / doi.org/10.21043/ziswaf.v4i1.3030.

5 Kumara Adji Kusuma, "Mengembangkan Indikator Ekonomi Islam Melalui Zakat: Sebuah Kerangka untuk Mengukur Kesejahteraan Masyarakat/Negara Muslim," May 28, 2016, http:/ / publikasiilmiah.ums.ac.id/handle/11617/7330. 
is an interconnected relationship between life in this world and life in the hereafter, in which one's behavior in this world has an impact on his life in the hereafter, good deeds in this world result in good rewards from Allah in the hereafter, and Allah will punish those bad things we do in this world. This indicator is expected to measure the level of welfare of a country based on the actual amount of wealth owned by Muslims. Authorities in an Islamic country or a country with a majority Muslim population can determine appropriate strategies and policies to increase the amount of zakat collection, especially by converting mustahik into muzakki, or by increasing the ability of muzakki to pay zakat to achieve Maqasid al-Shariah. The second benefit of this indicator is the collection of information about the types of assets that exist and are owned in the community so that they can be used for investment and other positive purposes. This is possible from the type of zakat paid, whether it is in the form of livestock, merchandise, fruits, honey, minerals, industry, factories, etc.

From the importance of the concept contained in Rahmatan Lil 'Alamin in realizing Indonesia's Economic Development in Era 4.0, its implementation needs to be known and developed to support it. So that researchers want to uncover and explore related 1) How does the value of Rahmatan Lil 'Alamin can be used to build Indonesia's economic development at 4.0 era from philosophical (Islamic economic) perspectives?, 2) How do the concepts of Rahmatan Lil 'Alamin in Islamic economic law can be manifested to realize Indonesia's Economic Development in Era 4.0?

\section{Method}

The type of research used is normative research with a library research approach. This research is categorized as a descriptiveanalytic type, which tries to describe and provide a comprehensive analysis of how the concept contained in Rahmatan Lil 'Alamin in realizing Indonesia's Economic Development in Era 4.0, and how the Implementation of the Rahmatan Lil 'Alamin Concept in realizing Indonesia's Economic Development in Era 4.0. This research is normative research, where research studies are obtained by studying literature on various documents and related literature. The data is processed and analyzed qualitatively. The research data was obtained from primary and secondary data taken from a literature review, 
starting from the study of Philosophy and Theory of Islamic Economic Law, as well as the implementation of the concept of Rahmatan Lil 'Alamin in realizing Islamic Economics through the Existence of Islamic Philosophy, Theory of Formation of Islamic Law, Values Islamic economic law philosophy, Measuring the Achievement of the Goals of Islamic Law (Economics), Philosophical construction in sharia economic contracts and Islamic Law Structuring and Views General philosophy of Islamic law (Maqāsid al-Shari'ah and conventional legal methodology of Islamic law al-figh) and also the philosophy of Rahmatan Lil 'Alamin in Islamic Economics 4.0 era, and the literature sources from official documents, previous research studies, journals, and other appropriate sources. Thus, the ending can be seen, the analysis, and drawn into a conclusion from the implementation of the concept of Rahmatan Lil 'Alamin in the era of the Industrial revolution 4.0 in economic development as it is today, especially through sharia economics.

\section{Discussion and Result}

Implementation of the Rahmatan Lil 'Alamin Concept in Era 4.0 as a Theory of the Formation of Islamic Law

Jasser Auda's perspective as research conducted by Mukhlishi explained that Maqashid Al-Shariah as the formation of Islamic law has no end. This means that the formation of Islamic law exists (the relativity of truth), which is essentially the end of the theory of the formation of Islamic law by using Maqashid Sharia needs to be developed by Muslim thinkers, to provide the needs and interests of the lives for the life of Muslims justice, mutual respect, and peace. ${ }^{6}$ This means that the implementation of the concept of Rahmatan Lil 'Alamin in Era 4.0 as a Theory of Formation of Islamic Law is a necessity. This is as research launched by Mustaqim which explains that Maqasid Al-Shari'Ah is Jasser Auda's version of Islamic legal

6 Mukhlishi, “Konsep Maqashid Al-Shariah Sebagai Teori Pembentukan Hukum Islam Tak Pernah Tuntas Perspektif Jasser Auda," Al-Ulum Jurnal Pemikiran Dan Penelitian Ke Islaman 1, no. 1 (February 6, 2014): 12-27, https://doi.org/10.31102/alulum.1.1.2014.12-27. 
philosophy ${ }^{7}$ is the idea of maqashid which is constantly changing and developing, which, based on the periodization of time, can be classified into four periods: the period of the Companions, the period of the madhhab imam, the period of development of maqashid theory from the $5^{\text {th }}$ to the $8^{\text {th }}$ century, and the contemporary period. Considering Jasser Auda, it seems that his views on maqashid are not much different from the previous ushul scholars. The completely new concept from Jasser Auda is when he places maqashid al-shari'ah as a philosophy of Islamic law. This means that maqashid al-shari'ah is placed as an independent discipline and is not one of the themes of the study of Usul fiqh. Therefore, maqashid al-shari'ah must function as the fundamental methodology in the workings of Usul fiqh. So that the concept of Rahmatan Lil 'Alamin in Era 4.0 as an Islamic Law Formation Theory needs to be developed according to the demands of the times by prioritizing high rationality without leaving the mainstream of religion, where the main points in the Usul fiqh language will be the basis for istinbath al-Islam. Ahkam al-Syar'iyah, the results of which will give birth to a new Theory of Formation of Islamic Law that is more relevant according to the demands of the times. ${ }^{8}$

In the development of the modern economy, the existence of ushul fiqh is very significant in determining the growth and development of the economic world, especially Islamic economics. Scholars now punish buying and selling transactions as they were in the early first century Hijri without regard to some of the differences in conditions between the two. Jalaluddin stated that the worldly benefits of humans and the means to achieve them will change as time changes. While the texts and qiyas methods that it brings are limited, they will not be enough to solve all the increasingly complex human problems. Therefore the existence of maqashid is needed. ${ }^{9}$ The connection with the concept of Rahmatan Lil 'Alamin in Era 4.0 as a

7 Mustaqim, "Maqasid Al-Shari'Ah Sebagai Filsafat Hukum Islam (Pendekatan Sistemik versi Jasser Auda)," Al-Mabsut: Jurnal Studi Islam dan Sosial 6, no. 1 (April 1, 2013): 1-19.

8 I. Nurol Aen, Dasar-Dasar Kaidah Kebahasaan Dalam Ushul Figh (Tasikmalaya : Lembaga Kajian Komunikasi dan Sosial (Lekkas), 2020).

9 Jalaluddin Abdurrahman, Mashalih Al-Mursalah Wa Makanatuha Fi al-Tasyri (Cairo : Darul Kitab al-Jami'iy, 1983), 88. 
Theory of the Formation of Islamic Law where the all-digital era like today is a necessity where the need is very necessary to answer the challenges of the times.

Maqashid Syari'ah Imam al-Syathiby, for example, tends to provide space for ijtihad for economists in making a real contribution to the development of the Islamic economy, both in concept and practical areas. Normatively it shows that Maqashid Syari'ah is very relevant in fulfilling Ijtihad in Islamic economics in the categories of Dharuriyat (primary), Hajiyat (secondary), and Tahsiniyah (Tertiary). ${ }^{10}$ Buzama $^{11}$, in his research, explained that Islamic law entered Indonesia at the same time as the entry of Islam into Indonesia, which according to some circles was from the $7^{\text {th }}$ or $8^{\text {th }}$ century AD. Meanwhile, Western law was only introduced by the VOC in the early $17^{\text {th }}$ century AD. Before the entry of Islamic law, the people of Indonesia adhered to customary law, which has various systems and is very diverse. Islam had a major influence on the lives of Indonesian people until now. In addition, most of the Indonesian population adheres to Islam, so it becomes natural if Islamic law always colors the national law in Indonesia. So with the concept of Rahmatan Lil 'Alamin in Era 4.0 in which an all-digital era like today requires development that is tailored to the needs of mujtahids, which when speaking in the Indonesian context, the MUI (Indonesian Ulema Council) must be able to answer problems and challenges in this disruption era.

Prospects of Islamic Law in the Indonesian Legal System as explained by Saifuddin ${ }^{12}$, in his research, is very easy to apply in Indonesia, without changing the state order, namely (1) through amendments to the Constitution, (2) through the transformation of legal material, and (3) through regional autonomy such as in Aceh, Banten, Madura, and Gorontalo. Examples such as the

10 Bustanul Arifin, “Eksistensi Maqasid al-Shari'ah Imam aL-Syathiby Dalam Perkembangan Hukum Ekonomi Syari'ah," At-Tahdzib: Jurnal Studi Islam dan Muamalah 3, no. 2 (2015): 75-99.

11 Khoiruddin Buzama, "Pemberlakuan Teori-Teori Hukum Islam di Indonesia," Al-'Adalah 10, no. 2 (2012): 467-72, https://doi.org/10.24042/adalah.v10i2.300.

12 Saifuddin, "Prospek Hukum Islam dalam Sistem Hukum Indonesia," Al'Adalah 14, no. 2 (2017): 461-82, https:/ / doi.org/10.24042/adalah.v14i2.2516. 
Contextualization of Al-Hisbah in Business Competition Law in Indonesia in the journal of Ninik Zakiyah, et al. ${ }^{13}$ It is explained that the contextualization of a Business Competition Law in Indonesia is evidenced by the existence of supervision of market activities and competition in Islam that has existed since the time of the Prophet and even at the same time became one of the duties of an employee called muhtasib (supervisor). Al-hisbah as a supervisory agency for economic activities and market competition aims to enforce the commandments of ma'ruf nahi munkar. KPPU, Commission for the Supervision of Business Competition, is tasked with overseeing the practice of prohibiting monopolies and unfair business competition in Indonesia with the principle of economic democracy. The facts show that in general, the KPPU is similar to the al-hisbah institution because the substance and values contained in the KPPU are the same as those in the al-hisbah institution, especially in the effort to enforce the commandments of ma'ruf nahi munkar in the economic field and market competition. The connection with the concept of Rahmatan Lil 'Alamin, as a Theory of Formation of Islamic Law, in Era 4.0 is the amendment of the laws that apply in Indonesia through a superior order without creating noisy divisions between ethnicities, religions, nations, and countries, a small example of the presence Islamic Economic Brand, halal industry, and cash waqf in Indonesia.

Maheasy alluded in his research regarding the issue to be up to date in developing Islamic law, which is the Contextualization of Sharia (Rahmatan Lil 'Alamin) and its Contribution to the Development of Indonesian National Law. The reason is very clear that Islam and Islamic Shari'a which was originally revealed in Mecca in $610 \mathrm{AD}$ is very flexible and contextual so it needs to be developed. Islam accepts the Hanif religion (the religion of Prophet Ibrahim) to perfect the Hanif religion which has been misunderstood, perpetuating the good and great teachings of the Hanif religion, and straightening its teachings to preserve its noble and priceless teachings. Islam also respects Arab traditions while at the same time preserving the noble and beneficial Arab traditions, and eradicating traditions that are no

13 Ninik Zakiyah et al., "Al-Hisbah Contextualization in the Business Competition Law in Indonesia," AL-'ADALAH 16, no. 2 (December 26, 2019): 249-62, https://doi.org/10.24042/adalah.v16i2.5365. 
longer useful. This is the most important nature of Islam according to Khalil Abdul Karim, which he calls the blueprint for the practice of Islam and Islamic law in the public sphere today. Religion is for humans because God the Most Just is very concerned about the reality of human social life. The law was also created to discipline people's lives; therefore the main concern is the benefit of human life, which in this context, the early history of sharia can be used as the basis for the application of Islamic law anywhere and anytime. ${ }^{14}$

There are three principles of Islamic economic philosophy as quoted by Ahmad M. Saefudin by Mohammad Daud Ali. First, the principle of all things in the universe, the heavens, the earth, and the natural resources, even the wealth owned by humans belongs to Allah as the Creator. All of Allah's creations are subject to His will and provisions (Surah 20:5). This principle has placed the issue of human ownership as relative ownership and God as the real owner. Second, the principle of monotheism, that Allah is one God. This principle means that humans as the Caliph of Allah on earth must manage all the facilities given by Allah to serve the one God, namely Allah SWT as the axis of human activity. Third, the principle of faith in the last day, namely the day of retribution for human deeds in various forms of activity, includes an economic activity. This principle places the basis for economic behavior in controlling divine values as the basis for the value that all human activities in the world will be held accountable at the end of the day. Thus, this principle is intended to build the level of human cognitive awareness that all human activities are always under God's control. Therefore there is no room for him to commit fraud in carrying out economic activities. The three main points of Islamic economic philosophy above gave birth to the basic values of the Islamic economic system. ${ }^{15}$ So that with the presence of the Rahmatan Lil 'Alamin Concept in Era 4.0 as the Theory of the Formation of Islamic Law, it becomes a real necessity and needs to be implemented immediately to answer the challenges of the times

14 Siti Mahmudah, "The Contextualization of Sharia and Its Contribution to The Development Of The Indonesian National Law," AL-'ADALAH 16, no. 1 (July 29, 2019): 17-40, https://doi.org/10.24042/adalah.v16i1.3393.

15 Mohammad Daud Ali, Sistem Ekonomi Islam Zakat Dan Wakaf (Jakarta: UI Press, 2006), 6. 
through various religious terms without oppressing other religions, but still muntij (optimistic) and not mustahliq (pessimistic).

Implementation of the Rahmatan Lil 'Alamin Concept as an Indicator of Achievement of the Goals of Islamic Economic Law

Hard-working as a basic human attitude to life is an Islamic work ethic whose main foundation is a person's belief system ${ }^{16}$ The Mudharabah Scheme in Islamic Banking is in the form of profitsharing and related problems in it ${ }^{17}$. There is a profit-sharing principle in the mudharabah scheme in Islamic banking. Mudharabah schemes are usually applied to financing and investment products that involve two parties: shahib al-maal and mudharib. Both parties work together to get the benefits that will be distributed according to the ratio agreed at the beginning of the contract. If there is a financial loss, the sahib almaal will bear all of it, but if it is caused by the negligence of the capital manager, the loss must be borne by the mudharib. In terms of measuring the achievement of the objectives of Islamic law in the field of economics, the main basis is when the contract is initiated, in which the mudharabah contract, which is the majority of Islamic banks, applies the revenue-sharing principle which is indirectly approved by Fatwa DSN 07/2000. The application of this principle can trigger a sense of injustice because profit sharing is calculated based on gross profit which is more profitable for the shahib al-maal and less profitable for the mudharib. Therefore, the indicators of achievement under the purpose of Islamic law in the field of Islamic economics are still less effective when viewed from the aspect of the contract alone.

In classical fiqh studies, mudharabah contracts are similar contracts to usual that do not have collateral provisions in them. Therefore, there is no need for collateral in the mudharabah, because the mudharabah contract is only based on the element of trust (amanah) so there is no need for guarantees given by customers to Islamic banks / financial institutions. As a result, the collateral in the

16 Ahmad Janan Asifudin, Etos Kerja Islami (Surakarta: Muhamadiyah Unniversiti Pres, 2004), 35.

17 Supriatna, Irpan Helmi, and Nurrohman, "Mudharabah Scheme Within The Islamic Banking: Profit Sharing And Associated Problems In It," Kodifikasia: LPPM Institut Agama Islam Negeri (IAIN) Ponorogo 14, no. 2 (2020), https://doi.org/0.21154/kodifikasia.v14i2.2121. 
mudharabah contract serves to avoid deviations from the fund managing customers so that they do not deviate from playing around in managing mudharabah financing funds, there is no need for guarantees and mandatory conditions for every mudharabah financing. Therefore, the LKS (the Islamic Financial Institution) can assign such guarantees to clients which serve to avoid moral hazard from the mudharib negligent or not under the contract, which is in line with the value of benefits in the Islamic transaction system. ${ }^{18}$ So in terms of measuring the achievement of the objectives of Islamic law (Economics) it can be seen in the transaction system used at the beginning of the mutually agreed contract/engagement.

The Percentage of the Poor in Indonesia in March 2020 was about 26.42 million people. It increased around 1.63 million against September 2019, and an increase of around 1.63 million against March 2019. Compared to September 2019, the number of poor people in March 2020 in urban areas rose by 1.3 million people (from 9.86 million people in September 2019 to 11.16 million people in March 2020). Meanwhile, rural areas increased by 333.9 thousand people (from 14.93 million people in September 2019 to 15.26 million people in March 2020). The Poverty Line in March 2020 was recorded at IDR $454,652 /$ capita/month with the composition of the Food Poverty Line of IDR 335,793,- and the Non-Food Poverty Line of IDR 118,859. In March 2020, on average, poor households in Indonesia had 4.66 household members. Thus, the size of the Poverty Line per poor household on average is IDR 2,118,678,-/ poor household/month. ${ }^{19}$ So from the statistical data above, its relationship with the Indicators of Achieving the Goals of Islamic Law (Economic Sector) is in the Überleitung /transitional category, which it means still needs assistance from the government to alleviate poverty in Indonesia. From this problem, it is needed a precise strategy in alleviating poverty, one of which is through measuring the Achievement of the

18 Maman Surahman and Mr Nurrohman, “Analysis Of Maqâshid Al-Syarî’ah On The Application Of The Collateral In The Mudhârabah Contract In Sharia Financial Institutions," Amwaluna: Jurnal Ekonomi dan Keuangan Syariah 4, no. 2 (July 31, 2020): 276-87, https://doi.org/10.29313/amwaluna.v4i2.5588.

19 BPS - Statistics Indonesia, "Badan Pusat Statistik," 2020,

https://www.bps.go.id/pressrelease/2020/07/15/1744/persentase-pendudukmiskin-maret-2020-naik-menjadi-9-78-persen.html. 
Goals of Islamic Law (Economics) by applying the concept of Rahmatan Lil 'Alamin in Islamic Economics (the principle of equitable justice).

Hossein Askari, a professor of international politics and business at George Washington University, USA, conducted a unique and interesting study. He carried out "in which country in the world are Islamic values most widely applied?". Askari's recorded 208 countries, not a single Islamic country, was able to rank in the top 25 . Instead, Askari found Ireland, Denmark, Luxembourg, and New Zealand as the top five most Islamic countries in the world. Other countries which implement the most real teachings of Islam are Sweden, Singapore, Finland, Norway, and Belgium. Malaysia stayed at 33rd. Other Islamic countries in the top 50 include Kuwait, which is in 48th place, while Saudi Arabia is 91st and Qatar is 111th. Based on his research, Askari ${ }^{20}$ said, most Islamic countries use religion as an instrument to control the state. However, there are still many countries that claim to be Islamic countries but often act unfairly, corruptly, and backward. Askari added it is precisely Western countries that reflect Islamic teachings, including in their economic development. Askari tried to compare Islamic ideals in terms of economic achievements, governance, people's rights, and political right, as well as international relations. Ireland, with 49,000 citizens converting to Islam, said Ali Selim, a senior member of the Irish Islamic Cultural Center (ICCI), saying that Muslims and other Irish can live side by side because they share a common history. Ireland was once a colony and several Irish suffer from racial discrimination and are always associated with terrorism, where Muslim immigrants in Ireland have the same opportunity to develop themselves, including in the economic field. The Quran encourages Muslims to live in prosperity and Dublin is one of the largest Islamic investment centers in Europe. ${ }^{21}$ According to Askari's research, the relation with

20 Scheherazade S. Rehman and Hossein Askari, "How Islamic Are Islamic Countries?," Global Economy Journal 10, no. 2 (May 21, 2010): 1850198, https://doi.org/10.2202/1524-5861.1614.

21 Kompas Cyber Media, "Studi: Irlandia, Negara Paling Islami di Dunia," Kompas.com, June 10, 2014,

https://internasional.kompas.com/read/xml/2014/06/10/2151008/Studi.Irlandia.N egara.Paling.Islami.di.Dunia. 
indicators in Measuring the Achievement of the Goals of the Islamic economic sector cannot be measured from certain country models, both from Muslim countries and non-Muslim countries. It can be done is by applying the concept of Rahmatan lil 'Alamin in economics (Transparent, healthy competition, continuously innovating according to the demands of the times). So it can be concluded that Rahmatan lil 'Alamin in Islamic economics is a market trick (siyasah Syar'iyyah) towards real benefit.

It was further mentioned regarding the countries that were ranked in the top 10 as reported in the Islamicity Index (Rehman and Askari), even though none of those countries are known as Islamic countries and members of the OIC, in carrying out the principles of Islamic economics, they are better than Muslim countries themselves.22 This is proof that the siyasa syar'iyyah through the concept of Rahmatan Lil 'Alamin needs to be applied from an early age to create a better economy for both Muslim and non-Muslim countries. This is as stated in his book Nasarudin Umar that living in a non-Muslim country is not easy, it is necessary to maintain strong faith and devotion, especially in matters of worship (Mahdhah and Ghairu Mahdhah). ${ }^{23}$ According to the researcher when doing mu'amalah especially in transactions, the concept of Rahmatan lil 'Alamin is the answer to the problems above. Furthermore, Nasarudin Umar said in his book "The Movement of Islam in the US" that compassion $^{24}$ Islam needs to be implanted so that the comparison between the thoughts of Muslims and non-Muslims is maintained so that the researcher believes that Rahmatan Lil 'Alamin has an accurate concept in realizing world peace.

22 Nurohman, Measuring the Achievement of the Goals of Islamic Law (Economics). Study Materials for the Postgraduate Doctoral Program at UIN Sunan Gunung Djati Bandung, Semester II (Two) in the Philosophy and Theory of Islamic Economic Law, Saturday 3 April 2021, 2021, 7., 2021.

23 Nasaruddin Umar, Geliat Islam Di Negeri Non-Muslim (Banten : PT Pustaka Alvabet, 2020).

24 Nasaruddin Umar, Geliat Islam Di Amerika Serikat (Jakarta : Amzah, 2020). 
Implementating the Rahmatan Lil 'Alamin Concept in Era 4.0 in Sharia Economic Contract

The philosophy of Islamic economic law cannot be separated from three patterns of relationship in terms of religion, but rather as a unit, namely the relationship between God, humans, and nature. This is asked a harmonious relationship among others. Islamic economics is a divine economy that is humanist and illuminates with morals, not only with lustful Mutmainnah (good) only. The philosophy of Islamic economic law has the basic nature of economic law with rabbinic and human characteristics. The rabbinic dimension places Allah SWT as the center of human consciousness in carrying out economic activities whose reflection gives birth to economic behavior with human insight that pivots on the application of the values of benefit, justice, and mutual benefit. There are two approaches used in understanding the concept of Islamic economic law: First, the qauliyah verses approach which is called the prescriptive normative approach. Second, the Kauniyyah approach is an empirical-positive-descriptive approach based on empirical sources through the process of formulating economic values inductively by considering the dimensions of human benefit which always move dynamically. Both approaches can be used at the same time, giving birth to a third approach, namely the convergence/complementary approach (complementary) so that it can produce the basic values of Islamic economics comprehensively. As a worship activity, economic or business activity in Islam must avoid harmful and prohibited things such as usury, excessive attitude (israf), reducing the scales, khiyanat, and gharar (speculative activities in business). ${ }^{25}$ This means that Sharia Economic Contracts in Era 4.0 need to sustain and improve the Rahmatan Lil 'Alamin Concept based on digitalization and that Sharia also contributes to global competition through the contracts that are currently in place in the economy. Furthermore this is also evidenced by the implementation of the MUI fatwa that seven contracts are allowed in Sharia-based

25 Ridwan, "Konstruksi filosofis akad-akad ekonomi syariah," Ijtihad: Jurnal Wacana Hukum Islam dan Kemanusiaan 15, no. 2 (2015): 257-74, https:// doi.org/10.18326/ijtihad.v15i2.257-274. 
fintech including sale and purchase contracts/Ba'i, Ijarah, Musyarakah, Mudharabah, Qaradh, Wakalah, and Wakalah bil ujrah. ${ }^{26}$

In this case, when it comes to Islamic economic contracts, Ridwan's research shows that conceptual disagreements over a contract's normative legitimacy and philosophical foundation are often the cause for issues. As a result, it has been discovered that numerous contracts in Islamic economic law are based on legal philosophical principles. God, man, and nature are the foundations of Islamic economic law. Religious and human knowledge combine to provide the basis for Islamic economic theory. When it comes to economic activities, the rabbinic perspective places God at the core of human awareness, whose reflection gives rise to human-minded economic activity that is based on benefits, justice, and mutual benefits. ${ }^{27}$ Philosophical construction of sharia contracts In Muamalah fiqh; there are many sorts of contracts that have different legal aims. To determine the legal aims on which the law is enforced, the legal objectives of many forms of Muamalah contracts will be further explored. Contracts in Islamic law are divided into three categories: exchange contracts, cooperation contracts, and trust-giving agreements to make the mapping of contracts in Islamic law easier. ${ }^{28}$

So that concerning the Implementation of the Rahmatan Lil 'Alamin concept in era 4.0 in sharia economic contracts, it is necessary to measure the relevance of the existing contracts. This is as a perfect human being in living his life process; humans take on different roles and professions according to their respective talents, interests, and expertise. This necessitates diversity and no human being can independently take care of and meet their proper needs alone without the help of others.

As for the structuring and view of Islamic law, Muhammad Shahrur's believes that the concept of thinking so far in some respects should have been reorganized. Moving on from the framework of thinking that puts forward the principle of the absence of synonymy, gives birth to products of thought that are different from the

${ }^{26}$ MUI, Nomor Fatwa: 138/DSN-MUI/V/2020; Tentang Penerapan Prinsip Syariah Dalam Mekanisme Kliring, Dan Penjaminan Penyelesaian Transaksi Bursa Atas Efek, 2020.

27 Ridwan, "Konstruksi filosofis akad-akad ekonomi syariah."

${ }^{28}$ Rachmat Syafei, Fiqih Muamalah (Bandung: Pustaka Setia, 2001), 1. 
understanding of the majority of scholars. In scientific discourse, a series of contributions of thought that he put forward without relating to his academic background deserves a proportional academic appreciation. The context of the verses of the Qur'an and Sunnah which he understood differently from the understanding of the majority led to the opening of shells for intellectual creation (ijtihad) whose initial intention was to align the validity of revelation with the rapid changes and developments of the existing situation. Shahrur's fame was also sustained by the controversy over his thinking. This phenomenon has triggered several scientists to compose works to criticize their thoughts, both for and against. Therefore, referring to these works is very helpful in exploring Shahrur's thoughts further. ${ }^{29}$

The basic values of Islamic economics include three things. First, the concept of ownership states that ownership in Islam is not absolute control over economic resources, but the ability to utilize them. Man's ownership of his wealth is limited by the limits of his life in this world. Ownership of natural resources that are related to people's livelihoods becomes public property and the control rests with the state. The second is the concept of a balance between worldly and ukhrawi values and between individual interests and common interests, a balance between rights and obligations. The third is the value of justice, namely justice in the process of production and consumption, distribution process, and fairness in the allocation of the results of economic activities by setting aside property obligations in the form of issuing zakat. These three basic values become the basic spirit for the instrumental values of Islamic economics. ${ }^{30}$ So that the Implementation of the Rahmatan Lil 'Alamin Concept in Era 4.0 in Islamic Economic Contracts today that needs to be emphasized is the concept of ownership, balance, and equitable justice.

In this case, it is related to the Western response to Islamic economics in the 4.0 era of Islamic Economics which is applied in various countries, including Islamic banking, or Indonesia it is also called Sharia Banking. Where the western world's response to sharia economics is that the Western economic system is intended to

29 Asriyati, "Penataan Dan Pandangan Hukum Islam Muhammad Shahrur," Mazahib 14, no. 1 (2015), https://doi.org/10.21093/mj.v14i1.334.

30 Ridwan, "Konstruksi filosofis akad-akad ekonomi syariah." 
embrace the Islamic economic system and support the existence of the Islamic economic system, as a result, the western world implements a free business system based on capitalism that prioritizes capital for economic development in the Islamic world. Second, the contribution of the western world to the economy in Indonesia is a necessity that incidentally is not an Islamic State. However, in its scope, Islamic law in Indonesia in this case the sharia economy is subject to the national economic system, although in Indonesia itself the sharia economic system and conventional economics in Indonesia have their legal umbrella. So that the Islamic economic system in Indonesia until now is an alternative concept for a prosperous economic system in Indonesia, one of which is a capitalist economic system, as long as do not contradict Islamic law, especially the Qur'an and al-Hadith. ${ }^{31}$ So that the implementation of the Rahmatan Lil 'Alamin concept in era 4.0 in Islamic economic contracts today also needs legal certainty nationally through siyasa syar'iyyah in Islamic law, especially in the field of Islamic economics by prioritizing contracts that are relevant to the demands of the times, such as with the presence of cash waqf in early 2021 ago. Moh. Cholid Wardi in his journal describes the application of cash waqf (money) in the pesantren environment in Madura which has its own uniqueness, namely the development of the waqf fund itself, where the pesantren's assets surrender their entire assets to the waqf body. Prenduan Sumenep Madura. ${ }^{32}$

Usûl al-fiqh and Maqāsid mostly confused people, especially Islamic law students. It is important to know the difference between the two branches of Islamic sciences. The structure, scope, and functional properties of the two sciences are different. ${ }^{33}$ Nurrohman

${ }^{31}$ Hisam Ahyani and Memet Slamet, "Respon Dunia Barat Terhadap Ekonomi Syariah Di Era Revolusi Industri 4.0," JPED (Jurnal Perspektif Ekonomi Darussalam) (Darussalam Journal of Economic Perspectives) 7, no. 1 (March 28, 2021), https://doi.org/10.24815/jped.v7i1.19277.

${ }^{32}$ Moch Cholid Wardi, "The Implementation Of Cash Waqf In The Pesantren Of AlAmien Prenduan Sumenep Regency Of Madura," AL-IHKAM: Jurnal Hukum E Pranata Sosial 11, no. 1 (July 3, 2016): 93-119, https:/ / doi.org/10.19105/allhkam.v11i1.860.

33 Sulaiman Lebbe and Dr Rifai, "General Philosophy of Islamic Law and Its Legal Methodology. (Maqāsid Al-Shari'ah and Usûl Al-Fiqh)," SSRN Scholarly Paper (Rochester, NY: Social Science Research Network, February 19, 2021), https:/ / papers.ssrn.com/abstract=3789249. 
Syarif 34 in his research explains that the revitalization of ideology from an Islamic perspective, both at the national and global levels, always leads to aspirations and demands to implement sharia or Islamic law in total (kaffah). In the Indonesian rule of law, such aspirations and demands cannot always be met. This is because the Indonesian state of law, from the beginning, was built based on a national spirit based on the principles of divinity, humanity, justice, and equality for every citizen before the law. Therefore, aspirations and demands for the application of Islamic law always experience obstacles if there are discriminatory elements or other elements that can eliminate the guarantees and protections for the human rights of citizens that have been guaranteed by the constitution. As a result, the implementation of the Rahmatan Lil 'Alamin concept in Era 4.0 in sharia economic contracts is an inspiring concept in building better Islamic law, especially in terms of sharia economic contracts with the spirit of nationality (overshadowing all mankind).

The origins and definitions of maslahat legal instruments that exist in the concept of the public interest have become the general central theme of Islamic legal philosophy. Indeed, in general philosophy, Islamic law determines what is good and bad for the Muslim community. The view of Muslim jurists expresses their opinion that God Almighty revealed His last divine message through His last prophet (Muhammad Saw) to secure the interests and welfare of mankind. God sends His divine messages to promote human interests according to the divine will. But in the view of Muslim jurists today it is difficult to define the basic idea of human interest. ${ }^{35}$ For example, in the case of cash waqf ${ }^{36}$ where the view of Islamic Economics in Indonesia regarding cash waqf is carried out as Law No. $41 / 2004$ concerning waqf where objects move, namely in "moving object waqf" which is manifested in the form of money. As a result, cash waqf in Indonesia in the industrial revolution 4.0 eras can

${ }^{34}$ Nurrohman Syarif, Islamic Shari'a in the Perspective of the State of Law Based on Pancasila, vol. 11, 2 vols. (Pandecta Research Law Journal, 2016).

35 Lebbe and Rifai, "General Philosophy of Islamic Law and Its Legal Methodology. (Maqāsid Al-Shari'ah and Usûl Al-Fiqh)."

${ }^{36}$ Hisam Ahyani and Muharir, "Perspektif Hukum Ekonomi Syariah Tentang Wakaf Uang Di Era Revolusi Industri 4.0," 2021,

http://ejournal.kopertais4.or.id/tapalkuda/index.php/lantabur/article/view/4184. 
prosper the economy of the community and also the state. Waqf is positioned as social worship where waqf in Law No. 41/2004 concerning waqf article 1 explains that waqf is the act of a wakif to separate or surrender part of his property to be used forever for worship purposes and also for welfare purposes according to Islamic sharia. These are the contracts that need to be developed according to the demands of the times where the Implementation of the Rahmatan Lil 'Alamin concept in era 4.0 in sharia economic contracts can answer the challenges of the present, later, and in the future.

In the thought of Islamic economic theology as research by Ahyani and Slamet ${ }^{37}$ It was explained that in the 4.0 era of Islamic economic theology, as it is today, Indonesia adheres to economic freedom, meaning that this freedom is required to always be Muslimfriendly. Therefore the Islamic Economic Theological Thinking Concept is a concept formed in order to realize the aspirations of Muslims regarding economic problems where the conception of Islamic economic theology has a significant effect on its adherents in concrete life. Such as practicing mu'amalah in terms of Islamic legal politics, Islamic Economic Politics, development strategies in halal tourism, ${ }^{38}$ dalam Halal Food, ${ }^{39}$ cash waqf transaction, ${ }^{40}$ and soon. Islamic economics is an alternative choice for a Muslim for several reasons, namely the principles of Islamic economics itself. As a result, Islamic moral philosophy in socio-economic development is primarily justice which can be proven by an equitable distribution of income, as well as equitable wealth. ${ }^{41}$

\footnotetext{
${ }^{37}$ Hisam Ahyani and Memet Slamet, "Pemikiran Teologi Ekonomi Islam Di Indonesia Era 4.0," March 29, 2021, 0.

${ }^{38}$ Hisam Ahyani, Muharir Muharir, and Widadatul Ulya, "Potensi Wisata Halal Kota Banjar, Jawa Barat di Era Revolusi Industri 4.0," Tornare: Journal of Sustainable and Research 3, no. 1 (January 12, 2021): 0, https://doi.org/10.24198/tornare.v3i1.31511. ${ }^{39}$ Ahyani Hisam et al., "The Potential Of Halal Food On The Economy Of The Community In The Era Of Industrial Revolution 4.0," Indonesia Journal of Halal 3, no. 2 (February 6, 2021): 112-28, https:/ / doi.org/10.14710/halal.v3i2.10244.

${ }^{40}$ Fahruddin Ali Sabri, "WAKAF UANG (Sebuah Alternatif Dalam Upaya Menyejahterakan Masyarakat)," AL-IHKAM: Jurnal Hukum E Pranata Sosial 8, no. 1 (2013): 40-54, https://doi.org/10.19105/al-lhkam.v8i1.339.

41 Zainal Abidin, “Keadilan Sosio-Ekonomi (Kajian Atas Distribusi Pendapatan Dan Kekayaan Yang Merata Dalam Perspektif Islâm)," AL-IHKAM: Jurnal Hukum $\mathcal{E}$ Pranata Sosial 2, no. 2 (2007): 257-72, https://doi.org/10.19105/al-lhkam.v2i2.2625.
} 
Besides the cash waqf at 4.0 eras above, the Islamic economic community in Indonesia in the 4.0 era as it is today in the field of fiqh muamalah has challenges when delaying installment payments, then the Islamic bank will implement a default payment system (failure of payment), this application should not exist in Islamic business transactions, but in the era of globalization as it is today in Islamic banking has become ijtihad maliah a necessity due to the demands of the times. ${ }^{42}$ Due to the growing Muslim population, rapid digitalization, high demand for halal products, and an integrated global economy, the halal industry has become one of the most important business segment. Both Muslims and non-Muslims are taking advantage of the enormous potential of the global Halal industry by developing their own products. Different segments of the halal ecosystem include halal food, muslim-friendly tourism as well as halal cosmetics and pharmaceuticals. Based on those facts, a strategy can be proposed by developing and incorporating sustainable halal values, such as Rahmatan Lil 'Alamin values, so that Indonesian government encourage Islamic economy development. Therefore, the Islamic economic development in Indonesia can benefit from the development of this sector.

\section{Conclusion}

From the explanation above, several conclusions can be drawn: 1) The concept of Rahmatan Lil 'Alamin (overshadowing the entire ummah) can make the Existence of Islamic Legal Philosophy, which is then implemented and developed through the Islamic economic system in Indonesia to achieve happiness in the world and the hereafter. Rahmatan Lil 'Alamin, with the existing conception of Islamic economic law philosophy, is based on the triangle concept, namely the philosophy of God, man, and nature. 2) Islamic Economics is manifested by applying social interests, such as waqf. The implementation of the concept of Rahmatan lil-alamin in Islamic economics is fundamental to just live, in the context of reducing social inequality in human life. In addition, another form of embodiment is

\footnotetext{
42 Taufiqurrahman Taufiqurrahman, "IJTIHÂD MUÂMALAH MÂLIYAH KONTEMPORER DI ERA GLOBALISASI," AL-IHKAM: Jurnal Hukum \& Pranata Sosial 2, no. 2 (2007): 183-202, https:/ / doi.org/10.19105/al-lhkam.v2i2.2621.
} 
economic freedom which demands to always be Muslim friendly. To conclude, the unique conception of Rahmatan Lil 'Alamin's offered will create new developments that adapt to the demands of the times such as cash waqf, halal industry, halal food, halal tourism, and so on, if it is applied seriously.

\section{Bibliography}

Abdurrahman, Jalaluddin. Mashalih Al-Mursalah Wa Makanatuha Fi alTasyri. Cairo : Darul Kitab al-Jami'iy, 1983.

Aen, I. Nurol. Dasar-Dasar Kaidah Kebahasaan Dalam Ushul Fiqh. Tasikmalaya: Lembaga Kajian Komunikasi dan Sosial (Lekkas), 2020.

Ahyani, Hisam and Muharir. "Perspektif Hukum Ekonomi Syariah Tentang Wakaf Uang Di Era Revolusi Industri 4.0," 2021. http://ejournal.kopertais4.or.id/tapalkuda/index.php/lantab ur/article/view/4184.

Ahyani, Hisam and Memet Slamet. "Respon Dunia Barat Terhadap Ekonomi Syariah Di Era Revolusi Industri 4.0." JPED (Jurnal Perspektif Ekonomi Darussalam) (Darussalam Journal of Economic Perspectives) 7, no. 1 (March 28, 2021). https://doi.org/10.24815/jped.v7i1.19277.

Ahyani, Hisam, Muharir Muharir, and Widadatul Ulya. "Potensi Wisata Halal Kota Banjar, Jawa Barat di Era Revolusi Industri 4.0." Tornare: Journal of Sustainable and Research 3, no. 1 (January 12, 2021): 4-12. https:// doi.org/10.24198/tornare.v3i1.31511.

Ahyani Hisam et al., "The Potential Of Halal Food On The Economy Of The Community In The Era Of Industrial Revolution 4.0," Indonesia Journal of Halal 3, no. 2 (February 6, 2021): 112-28, https:/ / doi.org/10.14710/halal.v3i2.10244

Arifin, Bustanul. "Eksistensi Maqasid al-Shari'ah Imam aL-Syathiby Dalam Perkembangan Hukum Ekonomi Syari'ah." At-Tahdzib: Jurnal Studi Islam dan Muamalah 3, no. 2 (2015): 75-99.

Asriyati. "Penataan Dan Pandangan Hukum Islam Muhammad Shahrur." Mazahib 14, no. 1 (2015). https://doi.org/10.21093/mj.v14i1.334.

Auda, Jasser. Maqasid Al-Shariah as Philosophy of Islamic Law. London: The International Institute of Islamic Thought, 2008.

BPS - Statistics Indonesia. “Badan Pusat Statistik,” 2020. 
https:/ /www.bps.go.id/pressrelease/2020/07/15/1744/pers

entase-penduduk-miskin-maret-2020-naik-menjadi-9-78-

persen.html.

Buzama, Khoiruddin. "Pemberlakuan Teori-Teori Hukum Islam di Indonesia." Al-'Adalah 10, no. 2 (2012): 467-72. https://doi.org/10.24042/adalah.v10i2.300.

Daud Ali, Mohammad. Sistem Ekonomi Islam Zakat Dan Wakaf. Jakarta : UI Press, 2006.

Fahruddin Ali Sabri, "WAKAF UANG (Sebuah Alternatif Dalam Upaya Menyejahterakan Masyarakat)," AL-IHKAM: Jurnal Hukum \& Pranata Sosial 8, no. 1 (2013): 40-54, https://doi.org/10.19105/al-lhkam.v8i1.339.

Hastuti, Qurratul 'Aini Wara. "Peran Lembaga Keuangan Syariah Penerima Wakaf Uang (LKS-PWU) Bagi Optimalisasi Wakaf Uang." Ziswaf: Jurnal Zakat Dan Wakaf 4, no. 1 (February 15, 2018): 41-54. https:/ / doi.org/10.21043/ ziswaf.v4i1.3030.

Janan Asifudin, Ahmad. Etos Kerja Islami. Surakarta: Muhamadiyah Unniversiti Pres, 2004.

Jaya, Asafri. Konsep Maqasid Al-Shari'ah Menurut As-Syathibi. Jakarta: Raja Grafindo Persada, 1996.

Kusuma, Kumara Adji. “Mengembangkan Indikator Ekonomi Islam Melalui Zakat: Sebuah Kerangka untuk Mengukur Kesejahteraan Masyarakat/Negara Muslim," May 28, 2016. http:// publikasiilmiah.ums.ac.id/handle/11617/7330.

Lebbe, Sulaiman, and Dr Rifai. "General Philosophy of Islamic Law and Its Legal Methodology. (Maqāsid Al-Shari'ah and Usûl AlFiqh)." SSRN Scholarly Paper. Rochester, NY: Social Science Research Network, February 19, 2021. https:/ / papers.ssrn.com/abstract $=3789249$.

Mahmudah, Siti. "The Contextualization of Sharia and Its Contribution to The Development Of The Indonesian National Law." AL-'ADALAH 16, no. 1 (July 29, 2019): 17-40. https://doi.org/10.24042/adalah.v16i1.3393.

Media, Kompas Cyber. "Studi: Irlandia, Negara Paling Islami di Dunia." Kompas.com, June 10, 2014.

https:/ / internasional.kompas.com/read/xml/2014/06/10/21 51008/Studi.Irlandia.Negara.Paling.Islami.di.Dunia. 
MUI. Nomor Fatwa: 138/DSN-MUI/V/2020; Tentang Penerapan Prinsip Syariah Dalam Mekanisme Kliring, Dan Penjaminan Penyelesaian Transaksi Bursa Atas Efek, 2020.

Mukhlishi. "Konsep Maqashid Al-Shariah Sebagai Teori Pembentukan Hukum Islam Tak Pernah Tuntas Perspektif Jasser Auda." Al-Ulum Jurnal Pemikiran Dan Penelitian Ke Islaman 1, no. 1 (February 6, 2014): 12-27. https://doi.org/10.31102/alulum.1.1.2014.12-27.

Mustaqim. "Maqasid Al-Shari'Ah Sebagai Filsafat Hukum Islam (Pendekatan Sistemik versi Jasser Auda)." Al-Mabsut: Jurnal Studi Islam dan Sosial 6, no. 1 (April 1, 2013): 1-19.

Nurohman. Measuring the Achievement of the Goals of Islamic Law (Economics). Study Materials for the Postgraduate Doctoral Program at UIN Sunan Gunung Djati Bandung, Semester II (Two) in the Philosophy and Theory of Islamic Economic Law, Saturday 3 April 2021, 2021, 7., 2021.

Rehman, Scheherazade S., and Hossein Askari. "How Islamic Are Islamic Countries?" Global Economy Journal 10, no. 2 (May 21, 2010): 1850198. https:/ / doi.org/10.2202/1524-5861.1614.

Ridwan. "Konstruksi filosofis akad-akad ekonomi syariah." Ijtihad: Jurnal Wacana Hukum Islam dan Kemanusiaan 15, no. 2 (2015): 257-74. https:/ / doi.org/10.18326/ijtihad.v15i2.257-274.

Rohman, Abdur. "Menyoal Filosofi 'An Taradin Pada Akad Jual Beli (Kajian Hukum Ekonomi Syariah Dalam Transaksi Jual Beli)." Et-Tijarie: Jurnal Hukum Dan Bisnis Syariah 3, no. 2 (2016). https://journal.trunojoyo.ac.id/ettijarie/article/view/3911.

Sabri, Fahruddin Ali. "Wakaf Uang (Sebuah Alternatif Dalam Upaya Menyejahterakan Masyarakat)." Al-Ihkam: Jurnal Hukum $\mathcal{E}$ Pranata Sosial 8, no. 1 (2013): 40-54.

https://doi.org/10.19105/al-lhkam.v8i1.339.

Saifuddin. "Prospek Hukum Islam dalam Sistem Hukum Indonesia." Al-'Adalah 14, no. 2 (2017): 461-82. https://doi.org/10.24042/adalah.v14i2.2516.

Supriatna, Irpan Helmi, and Nurrohman. "Mudharabah Scheme Within The Islamic Banking: Profit Sharing And Associated Problems In It." Kodifikasia: LPPM Institut Agama Islam Negeri (IAIN) Ponorogo 14, no. 2 (2020). https://doi.org/0.21154/kodifikasia.v14i2.2121. 
Surahman, Maman, and Mr Nurrohman. "Analysis Of Maqâshid AlSyarî'ah On The Application Of The Collateral In The Mudhârabah Contract In Sharia Financial Institutions." Amwaluna: Jurnal Ekonomi dan Keuangan Syariah 4, no. 2 (July 31, 2020): 276-87. https://doi.org/10.29313/amwaluna.v4i2.5588.

Syafei, Rachmat. Fiqih Muamalah. Bandung: Pustaka Setia, 2001.

Syarif, Nurrohman. Islamic Shari'a in the Perspective of the State of Law Based on Pancasila. Vol. 11. 2 vols. Pandecta Research Law Journal, 2016.

Taufiqurrahman. "Ijtihad Muamalah Maaliyah Kontemporer Di Era Globalisasi." AL-IHKAM: Jurnal Hukum E Pranata Sosial 2, no. 2 (2007): 183-202. https://doi.org/10.19105/al-lhkam.v2i2.2621.

Umar, Nasaruddin. Geliat Islam Di Amerika Serikat. Jakarta: Amzah, 2020.

- - - Geliat Islam Di Negeri Non-Muslim. Banten: PT Pustaka Alvabet, 2020.

Wardi, Moch Cholid. "The Implementation Of Cash Waqf In The Pesantren Of Al-Amien Prenduan Sumenep Regency Of Madura." AL-IHKAM: Jurnal Hukum \& Pranata Sosial 11, no. 1 (July 3, 2016): 93-119. https://doi.org/10.19105/allhkam.v11i1.860.

Yulma, Nur Liviasari, and Sri Herianingrum. "Peran Pemberdayaan Wakaf Tunai (Studi Kasus Pada BMT Amanah Ummah Surabaya)." Jurnal Ekonomi Syariah Teori Dan Terapan 3, no. 11 (2016): 856-71. https://doi.org/10.20473/vol3iss201611pp856871.

Zainal Abidin, "Keadilan Sosio-Ekonomi (Kajian Atas Distribusi Pendapatan Dan Kekayaan Yang Merata Dalam Perspektif Islâm)," AL-IHKAM: Jurnal Hukum \& Pranata Sosial 2, no. 2 (2007): 257-72, https:// doi.org/10.19105/al-lhkam.v2i2.2625.

Zakiyah, Ninik, Paramita Prananingtyas, Hari Sutra Disemadi, and Konstantin Gubanov. "Al-Hisbah Contextualization in the Business Competition Law in Indonesia." Al-'Adalah 16, no. 2 (December 26, 2019): 249-62.

https://doi.org/10.24042/ adalah.v16i2.5365. 